\title{
IMPLICATIONS OF THE SANCTIONS OF CAPTURE FOR CHILDREN SEXUAL CRIMES
}

\author{
By \\ Yusep Mulyana \\ University of Pasundan \\ Email: Yusepmulyana09@gmail.com
}

\begin{tabular}{l}
\hline \hline Article Info \\
\hline Articlehistory: \\
Received Nov 14, 2021 \\
Revised Dec 21, 2021 \\
Accepted Jan 19, 2022
\end{tabular}

Keywords:

Implications, Sanctions

Castration, Sexual Crime

\begin{abstract}
The regulation for chemical castration is contained in Law Number 17 of 2016 concerning Stipulation of Government Regulation in Lieu of Law Number 1 of 2016 concerning the Second Amendment to Law Number 23 of 2002 concerning Child Protection. Chemical castration sanctions through a long process are listed in article 81, article 82 and article 81A of Law Number 1 of 2016 as an additional punishment and it can be an option for law enforcement officers, especially judges as judges in the trial to give punishments with the aim of deterrence For the perpetrators, chemical castration sanctions are considered in accordance with the purpose of punishment. Criminal sanctions are one of the methods used to achieve the purpose of holding criminal penalties. The application of the castration penalty has not yet been implemented.
\end{abstract}

Thisisan open accessarticleundertheCC BY-SAlicense.

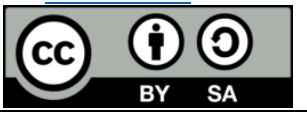

CorrespondingAuthor:

Yusep Mulyana,

University of Pasundan,

Email: Yusepmulyana09@gmail.com

\section{INTRODUCTION}

Based on the Law on Child Protection Number 35 of 2014Article 1 point 1, a child is someone who is not yet 18 (eighteen) years, including children who are still in the womb. Children have the right to protection regulated in various lawsstate, one of which is the Law of the Republic of Indonesia Number 391999 concerning Human Rights chapter 3, tenth chapter, article 52paragraph (1) which states that every child has the right to the protection ofparents, family, community and country; as well as paragraph (2) which statesthat children's rights are human rights and in the interests of children's rights they are recognized and protected by law even from the time they are conceived.

Children as the next generation of the nation have an important role in national development, they are obliged to get protection from the state in accordance with the provisions of the Constitution of the Republic of Indonesia of 1945 (UUD NRI 1945) which states that children have the right to protection from violence. The rapid flow of globalization and the negative impact of developments in the field of information and communication technology, gave rise toa new phenomenon of sexual violence against children.

Child sexual abuse is the involvement of a child inany form of sexual activity that occurs before the child reaches a certain age limit set by the law of the country where the adult or other children who are older or people who are considered to havemore knowledge than children use it for sexual pleasure or sexual activity. ${ }^{1}$

Child sexual abuse is a form of torturechild where an older adult or teenager uses the childfor sexual stimulation. Forms of child sexual abuse include soliciting or pressuring a child to engage in sexual activity (regardless of the outcome), providing indecent exposure of the genitals to a child, displaying pornography to a child, having sexual relations with children, physical contact with a child's genitals (except in certain non-sexual contexts

\footnotetext{
${ }^{1}$ Maslihah, S., "Play Therapy in Identifying Cases of Sexual Violence against Children", Journal of Psychological Research, Faculty of Psychology, Universitas Pendidikan Indonesia (UPI), Volume 1, Number 01, February, 2013, p.21.
} 
such as a medical examination), viewing a child's genitals without physical contact (except in a non-sexual context such as a medical examination), or using a child to produce child pornography.

The effects of sexual violence on children include depression, post-traumatic stress disorder, anxiety, a tendency to become victimized further in adulthood, and physical injury to the child among other problems. ${ }^{2}$

There are several reasons why children are often the target of violence namely: children are always in a weaker and helpless position, the morality of the community, especially the perpetrators of sexual violence is low, and the control and awareness of parents in anticipating crimes against children is low. ${ }^{3}$

It is natural for the protection of victims of child sexual violence to be strictly considered, this stepprojected so that they do not feel alone and the law is on their side. Handling perpetrators of sexual crimes requires proper handling multi-dimensional in the sense that there must be an effective criminal weighting systemto address the issue of sexual crimes against children.

Against this background, on May 25, 2016 the government through President Joko Widodo carried out a legal reform bysigned a Government Regulation in Lieu of Law (PERPPU) Number 1 of 2016 concerning Castration as an additional crime.

The Indonesian government expressly ratifies and enforces Government Regulation in Lieu of Law (PERPU) Number 1 Year2016 Regarding the Second Amendment to Law Number 23 of 2002Concerning Child Protection (State Gazette of the Republic of Indonesia Year 2016 Number 99, Promulgated in Jakarta 25 May 2016). On Change First with Law Number 35 of 2014 concerning Protection Child. ${ }^{4}$

The enactment of Law Number 17 of 2016 which started fromthe issuance of PERPU Number 1 of 2016 was motivated by the increase inthe number of sexual violence against children is significant and worryingendanger the lives and development of children, besides that it also disturbs the security and public order. Criminal sanctions imposed for perpetrators of sexual violence against children have not provided a deterrent effect and prevent sexual violence against children.

In Perpu Number 1 of 2016 contains the weighting of punishment in the form of Chemical Castration for perpetrators of sexual crimes against children who stated in Article 81 point (7) states "Against the perpetrators as referred to in paragraph (4) and paragraph (5) may be subject to action".in the form of chemical castration and installation of electronic detection devices. Castrated (also known as castration or castration) is a surgical procedureusing chemicals that aim to eliminate testicular function in males or ovarian function in females. Castration can be done wellin animals or humans. There are two kinds of castration applied in different countries, namely physical castration and chemical castration. Physical castration is doneby amputating the testicles of the perpetrators of pedophiles so as to makethe perpetrator lacks the hormone testosterone that affects the drivesexual. ${ }^{5}$

Ratification and enforcement of PERPU Number 1 of 2016 concerning the second amendment to Law Number 23 of 2002 concerning Child Protection certainly brings pros and cons. The pro arguecastration is necessary because cases of sexual violence are already in the stageemergency.

Amendments to the ChildProtection Act and weightsthe law on perpetrators of sexual violence against children is not very effective in reduce indecent acts against children. Evidently, thethe average sentence against the perpetrators is still relatively light. So that it has not succeeded in causing a deterrent effect to the perpetrators. Finally, cases of the same, even more heinous ones are still rampant in this country. ${ }^{6}$

Another consideration is that sexual crimes against minors are extra-ordinary crimes or external crimes normal, what else to cause the victim to die. ${ }^{7}$

${ }^{2}$ Arini Fauziah Al haq, et al., "Sexual Violence in Children in Indonesia", Journal of FISIP-UNPAD, Volume 2, Number 1, March, 2015, p. 16.

${ }^{3}$ Diesmy Humaira B, et al., "Sexual Violence in Children: A Study of the Relationship between Perpetrators and Victims of Vulnerability in Children", Journal of Islamic Psychology (JPI) Center for Psychological Research and Services, Volume 12, Number 2, August, 2015, p. 23.

${ }^{4}$ Yustitia's Vision Team, Consolidation of Child Protection Laws (UU RI NO. 23/2002 and UU RI NO. 35/2014), South Jakarta: PT Visimedia Pustaka, 2016, p. 34

${ }^{5}$ Muhammad Andi Dirgantara, Syafruddin Kallo, et al., "Juridical Analysis of Criminal Policy With Castration Punishment Against Pedophile Perpetrators", USU Law Journal, Volume 5, Number 1, September, 2017, p. 24

${ }^{6}$ Arliman, Laurensius S, "Law Number 17 of 2016 concerning Stipulation of Perppu 1 of 2016 as a Form of Child Protection from the Perspective of Constitutional Law", POSITUM Legal Journal, Volume 1, Number 2, March, 2017, p. 19

${ }^{7}$ Paat, Alfando, "The Relevance of the Castration Law to Sexual Crime Actors in Minors Judging from Law no. 39 of 1999 concerning Human Rights”, Journal of Lex Crimen, Volume 5, Number 5, March, 2017, p. 4 
International Journal of Social Science (IJSS)

Vol.1 Issue.5 February 2022 pp: 609-616

ISSN: 2798-3463 (Printed) | 2798-4079 (Online)

DOI: https://doi.org/10.53625/ijss.v1i5.1303

Sexuality crimes against minors are also seen as crimes against humanity, this is because minors should enjoy their absolute rights as a child as already stated.Formulated in Article 4 of Law Number 35 of 2014 concerning First Amendment to Law Number 23 Year 2002 concerningChild Protection which states that "Every child has the right to live, grow, develop, and participate fairly, in accordance with human dignity and dignity, and receive protection from violence and discrimination".

The opposing party rejects the castration sentence based on several arguments. There are those who refuse because they question its effectiveness in cause a deterrent effect. The purpose of the amplification of the sentence must be tryingin order to provide a deterrent effect for criminals and those who intend to commit crimes similar to the Perppu on Child Protection is considered not appropriate at this time.

There are at least a few reasons. First, the existence of the state does not depend on the Perpu that will be issued. It is certain that without the Perpu on Child Protection, the existence of this republic will still be maintained. Cases of sexual violence against children are indeed not an ordinary case, but they should not be viewed as a crisis that poses a real obstacle to the continuity of the state and the performance of the government.

Second, the act of issuing a Perpu on Child Protection can still be replaced by other actions, such as the enactment of a law. Third, the issuance of a Perpu can be assessed from the aspect of the background and its implications. If it's about. The urgency of the Perpu on Child Protection is still debated, so the implicationsgenerated is also not significant.

The Perpu on Child Protection has not been able to fully address the comprehensive prevention of sexual violence against children. Perpu as the ultimate weapon whose material only focuses on the weighting of penalties is not very effective. In fact, it would be better if the Perpu material stipulates 3 (three) things which are the main pillars of law enforcement. In addition to regulating the legal material (substance), this Perpu would be better if it also regulates the legal apparatus and the legal culture of the community in protecting children.

As an exampleThe rape case by Herry Wiryawan, a teacher at an Islamic boarding school in Bandung, West Java, has shocked the public. This depraved act was carried out by the perpetrators against 12 of his female students in a fairly long period of time, which was around 2016 to 2021.

Of the dozens of rape victims, some are pregnant and some have given birth. "The victims were 12 children, who gave birth to 8 , who were pregnant 2 . Not only did he rape, Herry apparently used the children born as a result of his depraved actions to ask for donations. Children born to rape victims were recognized as orphans, and used as a tool byperpetrators to ask for donations from a number of parties.

Indeed, the DPR still has time and opportunity to make changes to the Child Protection Law that are more comprehensive, what is needed is the good and sincere intentions of the President and the DPR to save the nation's generation. With a more focused discussion, it is hoped that the resulting product will be more solution-oriented in protecting children. ${ }^{8}$

Based on the description above, the formulation of the problem is:

1. How to Regulation Sanctions of Castration for Perpetrators of Sexual Crimes Against Children?

2. What are the Implications Sanctions of Castration for Perpetrators of Sexual Crimes Against Children?

\section{LITERATURE REVIEW}

\section{Definition and Regulation of Castration}

President Joko Widodo (Jokowi) issued Government Regulation Number 70 of 2020 concerning Procedures for Implementing Chemical Castration, Installation of Electronic Detection Devices, Rehabilitation, and Announcement of the Identity of Perpetrators of Sexual Violence against Children.

Quoting KBBI, castratedis the act of removing the function of the testes in males or ovaries in females. Castration also means that it has been sterilized.

Quoting PP 70 of 2020, this regulation was made to overcome sexual violence against children, provide a deterrent effect to perpetrators, and prevent sexual violence against children.

Article 1 paragraph (2) explains, Chemical Castration is the administration of chemical substances through injection or other methods, which are carried out to perpetrators who have been convicted for committing violence or threats of violence forcing a child to have intercourse with him or with other people, resulting in more victims than 1 (one) person, causing serious injury, mental disorder, infectious disease, disruption or loss of reproductive function, and/or the victim dies, to suppress excessive sexual desire, which is accompanied by rehabilitation.

Action chemical castration, the act of installing electronic detection equipment, and this rehabilitation is imposed on perpetrators of sexual intercourse based on a court decision that has permanent legal force.

${ }^{8}$ Ibid., p. 16 
The implementation of chemical castration, installation of electronic detection devices, and rehabilitation are carried out by officers who have competence in their fields on the orders of the prosecutor.

\section{Procedure for the Implementation of Chemical Castration}

Based on article 5, actions chemical castrationimposed for a maximum period of 2 (two) years. Nochemical castration this is done through several stages.

The stages are as follows:

\section{Clinical assessment}

The clinical assessment will be carried out by a team consisting of officers who have competence in the medical and psychiatry fields. Clinical assessment includes clinical and psychiatric interviews, physical examination, supporting examinations.

The procedures for clinical assessment are as follows:

a. The ministry that carries out government affairs in the field of law submits a notification to the prosecutor.

b. The notification as referred to in letter is made no later than 9 (nine) months before the convict finishes serving the main sentence.

c. Within 7 (seven) working days after the notification as referred to in letter b, the prosecutor submits the notification and coordinates with the ministry that administers government affairs in the health sector for clinical assessment.

d. Clinical assessment begins no later than 7 (seven) working days after receiving the notification as referred to in letter c.

\section{Conclusion}

This contains the results of clinical assessments to ensure that the perpetrators of sexual intercourse are eligible or not eligible for action chemical castration. This conclusion is submitted to the prosecutor no later than 14 (fourteen) working days after receiving the notification from the prosecutor.

\section{Implementation}

Implementation is carried out in the following manner:

a. The implementation of the Chemical Castration Action is carried out after the conclusion as referred to in Article 8 states that perpetrators of sexual intercourse are eligible to be subjected to chemical castration

b. Within a period of no later than 7 (seven) working days from the receipt of the conclusion as referred to in letter a, the prosecutor instructs the doctor to carry out the Chemical Castration Action on the Perpetrator of Sexual Intercourse.

c. The implementation of the Chemical Castration Act as referred to in letter b is carried out immediately after the convict has finished serving the main sentence.

d. The implementation of the Chemical Castration Action is carried out at a government-owned hospital or a designated regional hospital.

e. The implementation of the Chemical Castration Act was attended by prosecutors, representatives from the ministry in charge of government affairs in the legal field, the ministry in charge of government affairs in the social sector, and the ministry in charge of government affairs in the health sector.

f. The implementation of the Chemical Castration Action is stated in the official report.

g. The prosecutor informs the victim or the victim's family that the Chemical Castration Act has been carried out.

\section{Forms of Sexual Crime}

An important element of sexual harassment is the presence of unwilling nessor rejection of any form of attention of a sexual nature.So that it can be actions such as whistling, words, comments thataccording to local culture or manners (sense of morality) is reasonable.However, if it is not desired by the recipient of the act thenit can be categorized as sexual harassment.

Forms of sexual crimes are generally carried out by means of forcing the desire of only one party to seduce, poke, hug, and squeeze body parts, and all kinds of other forms of harassment until the main goal is to have forced intercourse.

In Indonesia, there are several laws concerning sexual crimes, as well as provisions in the Criminal Code concerning sexual violence, which can be seen in Chapter XIV concerning crimes against decency and several other laws.

a) Rape

The forms of sexual crimes are as follows: ${ }^{9}$

\footnotetext{
${ }^{9}$ Iqbal Ramdhani, "The Case of Sexual Harassment in Public Transportation According to the Decision of the Central Jakarta District Court", Social \& Cultural Journal of Syar-i FSH UIN Syarif Hidayatullah Jakarta, Volume 4, Number 1, 2017, p. 101
} 
International Journal of Social Science (IJSS)

Vol.1 Issue.5 February 2022 pp: 609-616

ISSN: 2798-3463 (Printed) | 2798-4079 (Online)

DOI: https://doi.org/10.53625/ijss.v1i5.1303

First, Rape. Rape can beinterpreted as an attackin the form of forced sexual intercourse, in a sexual attack there is a forced effort, violence, psychological pressure, abuse of power or taking opportunities from a coercive environment, in rape there is an element of coercion against the victim that makes the woman feel aggrieved, then Article 285 of the Criminal Code states " whoever by force or by threatviolence forces someone to have sex with men outside marriage, is threatened with rape with a maximum imprisonment of 12 years.

Rape is always synonymous with forced intercourse, self-copulation according to the formulaThe Criminal Code is the act of inserting the male genitalia into the female genitalia which generally results in pregnancy, and in other words when the penis secretes semen in the female genitalia. Therefore, if in the eventrape even though the male genitalia have been in the female genitalia for a long time, the male semen has not come out, it is not yet a rape, but an attempted rape.

The notion of intercourse is still a classical understanding and according to modern theory without even releasing semen, it can already be said to be intercourse so it is not appropriate if it is still considered an experiment. b) Sexual Harassment

Second, Sexual Harassment. This sexual harassment is an act through physical or non-physical touch, intentional or repeated, or non-consensual sexual intercourse. However, sexual harassment refers to an act that the victim finds unpleasant, because the act is intimidating, humiliating or disrespectful by making someone the object of sexual vent.

In the Criminal Code there are no articles that directly explain sexual harassment, but sexual crimes have been summarized in articles 289 to with article 296 regarding obscenity of the Criminal Code, because obscene acts are described as acts that violate decency and are included in sex crimes, for example kissing, groping memberspubic, fingering the breasts and so on.

It can be concluded that any act if it has been deemed to have violated decency or decency can be included in an obscene act, thus sexual harassment is an unwillingness or rejection of any form of sexual attention. This sexual harassment can be charged with the article of fornication article 289up to Article 296 of the Criminal Code. c) Sexual Exploitation

Sexual exploitation is the act of unequal abuse of power, or abuse of trust, for the purpose of sexual gratification, or for profit. The form that often occurs is using the poverty of a woman's family to enter her into prostitution or the pornography business.

Regarding sexual crimes, this form of exploitation is regulated in Law no. 44 of 2008 concerning Pornography Article 1, "Pornography is pictures, sketches, illustrations, photographs, writings,sounds, sounds, moving images,animations, cartoons, conversations, gestures, or other forms of messages through variousforms of communication media and or public performances, which contain obscenity or sexual exploitation that violates the norms of decency in society.

d) Trafficking of Women for Sexual Purposes

Trafficking of women for sexual purposes includes actsrecruiting, transporting, harboring, sending, transferring or receiving a person by coercion or seduction for the purpose of prostitution or sexual exploitation. The above crimes are listed in Law no. 21 of 2007 article 1 number 1 concerning Eradicationthe crime of trafficking in persons, "The act of recruiting, harboring, the transportation, delivery, transfer or receipt of a person by means of the threat of force, abduction, use of force, confinement, fraud, fraud, abuse of power or a position of vulnerability, payment or entrapment of money or benefits, so as to obtain the consent of the person holding control over other people, whether carried out between countries or within countries, for the purpose of exploiting or causing people to be exploited.

e) Sexual Slavery

Sexual slavery is a situation where the perpetrator feels he is the "owner"on the victim's body so that he has the right to do anything including obtaining sexual satisfaction through rape or other means. In the case of sexual slavery, it is regulated in the ActNo. 21 of 2007 concerning the criminal act of trafficking in persons, in a general explanation the definition of slavery is explained as follows: "Slavery is the condition of a person under the ownership of another.

Slavery-like practice is the act of placing someonein the power of another person so that that person is not able to refuse a job that is unlawfully ordered by that other person to him, even though that person does notwant it.

\section{METHODS}

The research method is descriptive analytical, which describes the problems and facts that occur based on positive legal norms, namely the laws related to this research. 
Approach method with normative juridical that is using positive legal norms related toImplications of Sanctions of Castration for Perpetrators of Sexual Crimes Against Children.

Data analysis was carried out qualitatively, meaning without using numbers and statistical formulas.

\section{RESULTS AND DISCUSSION}

Based on the provisions of Article 81 Paragraph 7 Perppu No. 1 Year 2016 regarding the Second Amendment to Law no. 23 of 2002 concerningChild Protection is a new type of punishment in Indonesia, namely castration, which is included in the criminal act. This crime of castration becomes the last criminal alternative (ultimum remidium) for pedophile perpetrators. This matter relevant to do because with the rise of cases of sexual violence children in Indonesia, in order to provide a deterrent effect for pedophiles andreparation for pedophile perpetrators so that they do not repeat the crimes they committed same.

Prevention of sexual violence can be done by 2(two) ways, namely overcoming by using legal channels (penal)and countermeasures outside the law (non-penal). In terms of dealing with legal channels, there are legal policies in terms of providing criminal sanctions against those who commit acts of sexual violence.

In the Criminal Code, several articles regulate the imposition of criminal sanctions (punishments), including Article 287, Article 288, Article 291, Article 292, Article 294, and Article 298.

Criminal sanctions are explicitly regulated in Article 10 of the Criminal Code. There are 2 (two) forms of criminal punishment, namely the main punishment and the additional punishment. The main punishments consist of the death penalty, imprisonment, confinement, fines, and imprisonment. Meanwhile, additional punishment consists of revocation of rights certain items, the confiscation of certain goods and the announcement of the judge's decision.

The punishment of castration is not stated in Article 10 of the Criminal Code, which means thatcastration is not included in the Indonesian criminal system. On the other hand, castration sentence violates Article 33 paragraph (1) of Law no. 39 years old2009 on Human Rights, which states that everyone the right to be free from cruel, inhuman or degrading human dignity and status.

The position of the criminal castration in the criminal system in Indonesiais not a principal, additional or aggravating punishment, but included in the criminal act. Article 81 paragraph 7 Perppu No. 1 Year 2016stressed, "against the perpetrators as referred to in paragraphs (4) and (5) may be subject to action in the form of chemical castration and chip installation".

The text of Article 81 paragraph 7 cannot be understood separately, because the reference that can be subject to criminal action for pedophile perpetrators must be reviewed in the previous paragraph, namely paragraph 4 and paragraph 5 .

This provision basically regulates the types of criminal acts of sexual violence against children based on who the perpetrator is (paragraph 4) and the consequences of the actions of the perpetrator (paragraph 5). If the perpetrator of sexual violence against children turns out to be a recidivist, they can be subject to action in the form of chemical castration.

This also applies to perpetrators based on the consequences of the perpetrator's actions, namely causing more than one victim, causing serious injuries, mental disorders, infectious diseases, loss of reproductive function, and/or the victim dies, these perpetrators are subject to chemical castration. .

This is in line with the sentencing objectives of the Combined Theory for provide a deterrent effect to perpetrators, but also provide guidance and recovery for pedophiles and reminding the publicnot to commit the crime. Meanwhile, the executor ofThe castration convict is carried out by the Indonesian National Police through a doctorpolice (doctoral).

The responsibility of the Dokpol is not to the Indonesian Doctors Association but to the State. In Indonesia, the regulation for chemical castration is stated in Law Number 17 of 2016 concerning Stipulation of Government Regulations in Lieu of Law Number 1 of 2016 concerning Second Amendment to Law Number 23 of 2002 concerningChild protection.

Chemical castration sanctions through a long process are listed in article 81 , article 82 and article $81 \mathrm{~A}$ of Law Number 1 of 2016 as an additional punishment and it can be an option for law enforcement officers, especially judges as judges in the trial to give punishment with the aim of deterrence forthe perpetrators, chemical castration sanctions are considered in accordance with thepurpose of punishment, criminal sanctions are one of the methods used toachieve the purpose of carrying out criminal penalties. 
International Journal of Social Science (IJSS)

Vol.1 Issue.5 February 2022 pp: 609-616

ISSN: 2798-3463 (Printed) | 2798-4079 (Online)

DOI: https://doi.org/10.53625/ijss.v1i5.1303

The application of the castration penalty has not yet been implemented. As for what becomesobstacles or obstacles in the implementation of the castration punishment is not yetthe existence of technical instructions in the Act to execute chemical castration punishment.

\section{CONCLUSION}

1. Regulations for chemical castration are contained in Law Number 17 of 2016 concerning Stipulation of Government Regulations in Lieu of Law Number 1 of 2016 concerning the Second Amendment to Law Number 23 of 2002 concerning Child Protection. Chemical castration sanctions through a long process are listed in article 81, article 82 and article $81 \mathrm{~A}$ of Law Number 1 of 2016 as an additional punishment and it can be an option for law enforcement officers, especially judges as judges in the trial to give punishments with the aim of deterrence For the perpetrators, chemical castration sanctions are considered in accordance with the purpose of punishment. Criminal sanctions are one of the methods used to achieve the purpose of holding criminal penalties.

2. The application of the castration penalty has not yet been implemented. The obstacle or obstacle in implementing the castrationpunishment is the absence of technical instructions in the law to execute chemical castration punishment.

\section{SUGGESTION}

1. The government, in this case members of the national legislative council, needs to review Law No. 1 of 2016 or make recent changes to the old law by involving the Indonesian Doctors Association to find the right solution so that the contra that is still rolling can be resolved immediately.

2. It is necessary to form a special team from the Police Doctor (Dokpol) to carry out the execution of castration and revision of the Regulations Indonesian National Police Number 12 of 2011 concerning Medicine Police to add Police Medical skills and increase the authority of Police Doctors as executor.

\section{REFERENCE}

[1] Arini Fauziah Al haq, et al., "Sexual Violence in Children in Indonesia", Journal of FISIP-UNPAD, Volume 2, Number 1, March, 2015

[2] Arief, BN, Anthology of Criminal Law Policy (Development Drafting of the New Criminal Code Concept), cet. to 4. Kencana, Jakarta, 2014.

[3] Chazawi, Adami, Criminal Law Lessons Part 1 Criminal System, Action Criminal Law, Criminal Theories, and Limits on the Application of Criminal Law, PT Raja Grafindo Persada, Jakarta, 2012.

[4] Diesmy Humaira B, et al., "Sexual Violence in Children: A Study of the Relationship between Perpetrators and Victims of Vulnerability in Children", Journal of Islamic Psychology (JPI) Center for Psychological Research and Services, Volume 12, Number 2, August, 2015.

[5] Hiariej, EO, Principles of Criminal Law, Cahaya Atma Pustaka, Yogyakarta, 2016.

[6] Huraerah, Abu, Violence Against Children, Nuance, Bandung, 2012.

[7] Jhonny Ibrahim, Theory and Research Methodology of Normative Law, Bayumedia Publishing, Malang, 2006.

[8] Kartanegara, Satochid, Criminal Law Part One, Lektur Hall Students, Jakarta, 2001.

[9] Marpaung, Leden, Theoretical Principles of Criminal Law Practice, Sinar Graphic, Jakarta, 2009.

[10] Maslihah, S., "Play Therapy in Identifying Cases of Sexual Violence against Children", Journal of Psychological Research, Faculty of Psychology, Universitas Pendidikan Indonesia (UPI), Volume 1, Number 01, February, 2017

[11] Muladi and Barda Nawawi Arief, Anthology of Criminal Law, Alumni, Bandung, 1992.

[12] Paat, Alfando, "The Relevance of the Castration Law to Sexual Crime Actors in Minors Judging from Law no. 39 of 1999 concerning Human Rights", Journal of Lex Crimen, Volume 5, Number 5, March, 2017.

[13] Priyatno, Dwidja, Implementing Imprisonment System in Indonesia, PT. Rafika Aditama, Bandung 2009.

[14] Teguh Prasetyo and Abdul Halim Barkatullah, Politics of Criminal Law (Criminalization and Decriminalization Policy Studies), Student Library, Jakarta, 2005.

[15] Yustitia's Vision Team, Consolidation of Child Protection Laws (UU RI NO. 23/2002 and RI Law NO. 35/2014), PT Visimedia Pustaka, South Jakarta, 2016. 
